\title{
Banking Reforms and the Effect on Economic Development of Nigeria
}

\author{
Ifeanyi O. Nwanna (Ph.D) ${ }^{1}$ John, Emmanuel Isaac ${ }^{2}$ \\ Department of Banking \& Finance,Nnamdi Azikiwe University,Awka
}

\begin{abstract}
This study examined the effect of banking reforms on economic development of Nigeria for the period 1986 - 2014. Data for the study were sourced from Central Bank of Nigeria Statistical Bulletins, publications of National Bureau of Statistics and Annual Reports of Deposit Money Banks. Ordinary Least Square (OLS) regression was employed for the analysis using Gretl 1.9.8 econometric software. The study revealed that Minimum Capital Base of Banks has a positive and significant effect on Gross Domestic Product. It was also found that Banks' Minimum Capital Base has a negative and significant effect on Inflation. However, it was observed that Banks' Minimum Capital Base has a significant positive effect on Unemployment. Thus, the study concluded that Minimum Capital Requirement of banks is a veritable reform on banks in Nigeria as it yields a positive result with regards to the economic development of the country. The study therefore, recommended that the monetary authorities should always take Minimum Capital Base of banks into consideration in banking reforms as it has the capacity to trigger economic development of Nigeria. Also, the study pointed out that the increase in Minimum Capital Base of banks should be done with caution so as not to increase unemployment.
\end{abstract}

Keywords: Banking Reforms, Deposit Money Banks, Economic Development, Minimum Capital Base

\subsection{Background of the study.}

\section{INTRODUCTION}

High economic growth and development that lead to a significant reduction in poverty and unemployment rate is one of the cardinal objectives of developing countries like Nigeria (Bamidele, 1998)[1]. Evidences have shown that financial institutions are necessary ingredients in the development process \{Lewis, 1955[2]; Schumpeter, 1934(2012)[3]\}. The Nigerian government having realized that adequate supply of credit to the economy is a crucial factor for development process, have introduced several reforms to boost the growth of the banking sector thereby boosting the economic development and reducing the rates of poverty and unemployment in the country. The fact that these various reform efforts have resulted in growth in the number, size or strength of financial institutions and instruments, it is of paramount importance to note that, these cannot be taken as evidence of economic development that is accompanied by growth in the real sector. Despite the numerous reforms, the rate of development of the Nigerian economy has been quite discouraging over the years. A quick look at some basic economic indicators confirms this assertion.

Furthermore, although Nigeria is regarded as an oil rich economy and the fact that the 2014 rebasing of the economy placed it as the largest economy in Africa, the well-being and the standard of living of the people are very low. The economy that is blessed with abundant natural resources and potential human resources has been wallowing in severe poverty. Available data shows that Nigeria especially her non-oil economy is declining over the years in productivity as is evident in declining total factor productivity (World Bank, 2006)[4]. Hence, the existence of a significant output gap in the economy is not in doubt.

\section{STATEMENT OF PROBLEM}

The CBN's capacity to provide an effective supervision of the financial services industry with the shape of the regulatory framework that is envisaged under its reform plans. Bankers have argued that the Central Bank of Nigeria has been experimenting with the economy various types of banking models. In the early days they said it was specialized banks that dominated the Nigerian landscape as directed by the CBN. They argued that the CBN in the early 70s adopted the rural banking programme which compelled all banks operating in the country to open rural branches. The programme was later abandoned because it could not meet the CBN set goals, the Federal Government in the 80s again came up with the idea of community banking which sought to encourage banking culture at the grass root. The CBN took over the control and regulation of these community banks through its other Financial Institution Department and it could not manage them and most collapsed under poor capital base. To replace community banks they further recalled that the CBN developed a framework for 
the conversion of community banks to micro-finance and as of today the scheme is also a monumental failure. Universal banking license was introduced by the CBN before the consolidation exercise. At the time there were about 93 banks in the country.

The consolidation exercise required banks operating in Nigeria to increase its paid up share capital to N25 billion, otherwise they were encouraged to merge with others banks to attain the minimum capital base. Nigerian banking system is second largest in Africa but is still small. Financial sector development can be a powerful agent for growth and transformation. Nigeria has plenty of headroom here. Open access should be the watchword helped by technology and by nimble regulation. Achieving this requires a champion who will understand the symbiotic relationships between financial sector development and real sector developments, a deeper understanding of demand-supply interactions for financial services, the need for product innovation and institution innovation in financial service provision, which are firmly anchored in local conditions.

\section{OBJECTIVES OF THE STUDY}

Therefore, this questions whether the reform programmes initiated in the banking sector have achieved its objectives. It is to this end that this research work seeks to examine the effect of banking reforms on the economic development of Nigeria.

\subsection{Research Questions}

The study is guided by the following specific questions:

1. To examine the effect of banks' minimum capital base on gross domestic product in Nigeria

2. To assess the effect of banks' minimum capital base on inflation in Nigeria

3. To determine the effect of banks' minimum capital base on unemployment in Nigeria

\subsection{Research Hypotheses}

The hypotheses stated in their null forms will be tested in the course of this study:

Hypothesis 1:

$\mathrm{H}_{0}$ : Banks' minimum capital base has no significant positive effect on gross domestic product in Nigeria.

Hypothesis 2:

$\mathrm{H}_{0}$ : Banks' minimum capital base has no significant positive effect on inflation in Nigeria.

Hypothesis 3:

$\mathrm{H}_{0}$ : Banks' minimum capital base has no significant positive effect on unemployment in Nigeria.

\subsection{Scope of the Study}

This study covers the banking sector reforms in terms of the minimum capital requirement of commercial banks in Nigeria and some national economic development indicators such as gross domestic product, inflation and unemployment for the period 1986-2014.

\subsection{The Significance of the Study}

The study is important to:

1. The Monetary Authorities: The outcome of this work gives a clear understanding of how effective the banking reforms are, and what needs to be done.

2. The Government: From the outcome of this research work, the government is informed of whether the needed economic development is achieved or not.

3. Banks: Through this work, the banks are informed on the effectiveness of their role with respect to the reforms undergone.

4. Researcher: this work serves as a reference materials for further research in this area of study.

\subsection{Conceptual Framework}

\section{REVIEW OF RELATED LITERATURE}

Economic development is the primary objective of the majority of the world's nations. This truth is accepted without controversy, or so it would appear in public discourse at least. Raising the well-being and socio economic capabilities of peoples everywhere is easily the most crucial social task facing us today. Every year, aid is disbursed, investments are undertaken, policies are framed, and elaborate plans hatched to achieve this goal, or at least to get closer to it.

Economic development in a wider sense involves increase in per capita income, reduction in unemployment, increase in gross domestic product, decrease in inflation, removal of poverty and under nutrition, increase in life expectancy, access to sanitation, clean drinking water, and health services, reduction of infant mortality; increased access to knowledge, schooling, and literacy. When a country is developed, it is a nation in which people are well fed and well clothed, have access to a variety of goods and services, possess the 
luxury of leisure and entertainment, and lives in a healthy environment. It also entails a society free of violent discrimination, with tolerable levels of equality, where the sick receive proper medical care and people do not have to sleep on the sidewalks. Development goes further to include political rights and freedoms, intellectual and cultural development, stability of the family, a low crime rate, social civility etcetera.

Ango (2011)[5] opinioned that banking reform in Nigeria started from 1952 when the first Banking Ordinance was enacted through to the 1959 when the CBN was established all through to the Structural Adjustment Programme (SAP) of 1986. Hesse (2005)[6] reported that the number of banks rose from 40 in 1985 to over 100 in 1990 . He attributed this to the new opportunities arbitraging opportunities in the newly introduced foreign exchange market. The reviews of CBN Act in 2007 gave the CBN the powers of issuance and revocation of bank licenses without recourse to Federal Ministry of Finance and to act generally in management of the sector (Ango, 2011)[5]. It was as a follow-up to that that the CBN issued its circular BSD/DO/CIR/VS1.L/10/2000 which gave commercial and merchant banks the option of converting into universal banks. The CBN power to increase the size of capital for Deposit Money Banks (DMBs) was derived from the various CBN Acts. In 2004, the minimum capital requirement of commercial banks was raise to N 25 million in an effort to strengthen the banks.

\subsection{Theoretical Framework}

This research work is backed by the Theory of Financial Intermediation. The theory according to Daramola (2012)[7] explains a situation in which an institution (which takes deposit) mobilizes idle funds from savers and channels same to those in need of the funds for investment purposes. This role is played by financial institutions (banks) in an economy. Thus, the proper functioning and performance of these institutions will facilitate economic development of the country.

Improving the Quality of Market Signals: A recent line of research has examined whether supervisory or regulatory measures could improve the reliability of market signals. One area is improving public disclosure among banking organizations. While there is little empirical work on the effectiveness of increased public disclosures, several studies have identified areas for improvements Spiegel and Yamori (2003)[8]. The Basel Committee on Banking Supervision published several studies and the Federal Reserve Board of Governors Staff Study (2000)[9] deals specifically with improving public disclosure among banking organizations. Improved disclosure also is part of Pillar 3 of the Basel II Accord. Most of the empirical analysis relating to improving the reliability of market signals in banking has focused on the issuance of debt. The findings are relevant for addressing several of the shortcomings of market signals from banking-related debt from the perspective of bank supervision-limited issuance, infrequent issuance, and thin secondary market trading, especially for debt issued directly by commercial banks.

For market signals from either debt or equity instruments to be useful in bank supervision, it is necessary to have sufficient transparency in banking so that market signals have an acceptable degree of reliability. The observations that many assets, such as loans, held by banks tend to be opaque raises the concern that the makeup of bank portfolios presents a significant hurdle for the market's ability to evaluate the financial condition, performance, and risk of banking organizations (Flannery, Kwan, and Nimalendran 2004) [10].

\subsection{Empirical Review}

Imoughele et al (2013)[11] carried out a study on the impact of commercial bank credit accessibility and sectoral output performance in Nigeria economy for period of 1986 to 2010, using OLS techniques. The study found that cumulative supply and demand for credit in the previous period has direct and significant impact on the growth of agriculture, manufacturing and the service sector output. The study attributed the development to the importance of credit facility as an input in the production process and persistent inflow to the manufacturing, agriculture and services sectors. The study further encourage continuous credit accessibility in a deregulated financial market economy as it has the capacity to induce the national real sector outputs, which would subsequently result to economic growth and development

Omankhanlen (2012)[12] examined the financial sector reforms and its effect on the Nigerian economy from 1980 - 2008, using OLS method. Financial intermediation was found to be necessary condition for stimulating investment, raising productive capacity and fostering economic growth.Fadare (2010)[13] investigated the effect of banking sector reforms on economic growth in Nigeria over the period of 1999 - 2009, using OLS regression technique. The study found that interest rate margins, parallel market premiums, total banking sector credit to the private sector, inflation rate, size of banking sector, capital and cash reserve ratios account for a very high proportion of the variation in economic growth in the country. Ayadi et al(2013)[14] explore the relationship between financial sector development and economic growth across the Mediterranean, using data covering the period of 1985 - 2009. The study found that credit to the private sector and bank 
deposits are negatively associated with growth, which in the authors' opinion, portend deficiencies in credit allocation in the region and suggest weak financial regulation and supervision.

Abu-Zeinab (2013)[15] reviews patterns of bank credit allocation and economic growth in Sweden over the period of $1736-2012$, and found that banking system exhibits tendency of reallocating bank credit toward service and trade activities for onward economic growth in the country. The results of Granger causality test and estimated regression models conducted by Akpansung and Babalola (2012)[16] indicate that private sector credit impacts positively on economic growth in Nigeria over the period 1970-2008. The study established that lending rate impedes growth, and recommends the need for more financial market development that favours more credit to the private sector to stimulate economic growth.

Bhusal (2012)[17] investigates the impact of policy reforms on financial development and economic growth in Nepal, using exogenous break test, and time series data ranging from 1965 to 2009. The study could not establish positive relationship between bank domestic credit and economic growth. The study suggests that the finding might be due to some problems which inhibit the banking sector in the country, such as inadequate expansion of commercial banks and their branches in the rural non-monetized sector, non-performing loans that discouraged credit allocation, among others.

Abubakar and Gani (2013)[18] in their study on impact of banking sector development on economic growth, using Vector Error Correction Modeling (VECM) with data covering the period of 1970 - 2010, found a negative relationship between credit to the private sector and economic growth, due to unfavorable feat of credit going into real sector. The study emphasized on financial deepening towards real sector.

Tomola et al (2010)[19] investigated the effect of bank lending and economic growth on the manufacturing output in Nigeria, using time series data covering the period of 36 years. They also employed cointegration and vector error correction model (VECM) techniques to analyze the data. It was found that manufacturing capacity utilization and bank lending rates significantly affect manufacturing output in Nigeria. The study recommended that policies that would foster investment friendly lending and borrowing by the financial institutions should be put in place by the appropriate authority.

\subsection{Sources of Data}

\section{RESEARCH METHODOLOGY}

The study employed ex post facto research design. It used secondary data sourced from Central Bank of Nigeria Statistical Bulletin, publications of the National Bureau of Statistics and Annual Reports of Banks. Ordinary Least Square (OLS) regression is employed for the analysis of the data. Three simple models were specified to guide the simple regression analyses.

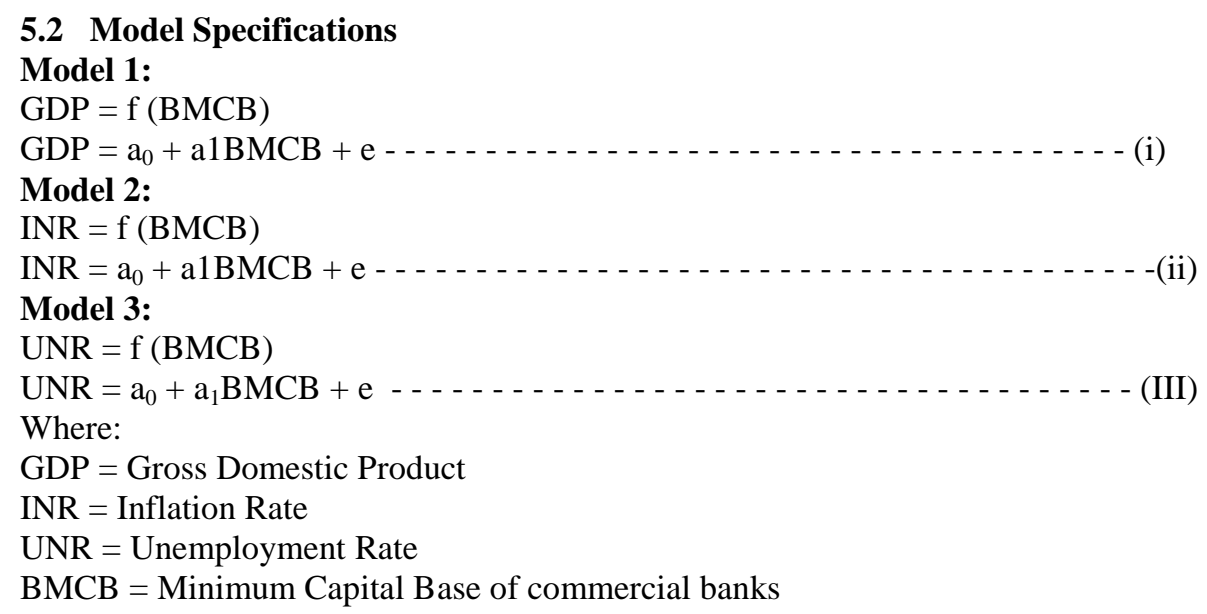

VI. DATA PRESENTATION, ANALYSIS AND DISCUSSION OF RESULT

Table 6.1: Nigeria's GDP, Inflation Rate, Unemployment Rate and Banks' Minimum Capital Base from 1986 to 2014

\begin{tabular}{|l|l|l|l|l|}
\hline Year & GDP & Inflation Rate & Unemployment Rate & Banks' Minimum Capital Base \\
\hline 1986 & 69146.99 & 5.4 & 5.3 & 600000 \\
\hline 1987 & 105222.84 & 10.2 & 7 & 600000 \\
\hline 1988 & 139085.3 & 38.3 & 5.1 & 5000000 \\
\hline 1989 & 216797.54 & 40.9 & 4.5 & 20000000 \\
\hline 1990 & 267549.99 & 7.5 & 3.5 & 20000000 \\
\hline 1991 & 312139.74 & 13 & 3.1 & 50000000 \\
\hline
\end{tabular}


Banking Reforms And The Effect On Economic Development Of Nigeria

\begin{tabular}{|l|l|l|l|l|}
\hline 1992 & 532613.83 & 44.5 & 3.5 & 50000000 \\
\hline 1993 & 683869.79 & 57.2 & 3.4 & 50000000 \\
\hline 1994 & 899863.22 & 57 & 3.2 & 50000000 \\
\hline 1995 & 1933211.55 & 72.8 & 1.9 & 50000000 \\
\hline 1996 & 2702719.13 & 29.3 & 2.8 & 50000000 \\
\hline 1997 & 2801972.58 & 8.5 & 3.4 & 500000000 \\
\hline 1998 & 2708430.86 & 10 & 3.5 & 500000000 \\
\hline 1999 & 3194014.97 & 6.6 & 17.5 & 1000000000 \\
\hline 2000 & 4582127.29 & 6.9 & 18.1 & 1000000000 \\
\hline 2001 & 4725086 & 18.9 & 13.7 & 2000000000 \\
\hline 2002 & 6912381.25 & 12.9 & 12.2 & 2000000000 \\
\hline 2003 & 8487031.57 & 14 & 14.8 & 2000000000 \\
\hline 2004 & 11411066.91 & 15 & 11.8 & 25000000000 \\
\hline 2005 & 14572239.12 & 17.8 & 11.9 & 25000000000 \\
\hline 2006 & 18564594.73 & 8.2 & 12.3 & 25000000000 \\
\hline 2007 & 20657317.67 & 5.4 & 12.7 & 25000000000 \\
\hline 2008 & 24296329.29 & 11.6 & 14.9 & 25000000000 \\
\hline 2009 & 24794238.66 & 12.4 & 19.7 & 25000000000 \\
\hline 2010 & 54204800000 & 13.2 & 21.1 & 25000000000 \\
\hline 2011 & 56964100000 & 10.84 & 23.9 & 25000000000 \\
\hline 2012 & 60755000000 & 12.52 & 24.3 & 25000000000 \\
\hline 2013 & 65259000000 & 8.52 & 29.5 & 25000000000 \\
\hline 2014 & 69421000000 & 9.6 & 30.1 & 25000000000 \\
\hline
\end{tabular}

Source: CBN Statistical Bulletin various issues

The data presented in Table 6.1 was used for the analysis. The results are presented in Tables 6. 2, 6.3 and 6.4.

Table 6. 2: Regression Result for Model 1

Model 1: OLS, using observations 1986-2014 $(\mathrm{T}=29)$

Dependent variable: GDP

\begin{tabular}{|l|l|l|l|l|l|}
\hline & Coefficient & Std. Error & t-ratio & $p$-value & \\
\hline Const & $-5.6248 \mathrm{e}+08$ & $4.72272 \mathrm{e}+09$ & -0.1191 & 0.90608 & \\
\hline BMCB & 1.13553 & 0.306406 & 3.7060 & 0.00096 & $* * *$ \\
\hline
\end{tabular}

\begin{tabular}{|l|c|l|l|}
\hline Mean dependent var & $1.06 \mathrm{e}+10$ & S.D. dependent var & $2.37 \mathrm{e}+10$ \\
\hline Sum squared resid & $1.04 \mathrm{e}+22$ & S.E. of regression & $1.96 \mathrm{e}+10$ \\
\hline R-squared & 0.337167 & Adjusted R-squared & 0.312618 \\
\hline $\mathrm{F}(1,27)$ & 13.73424 & P-value(F) & 0.000958 \\
\hline Log-likelihood & -727.4123 & Akaike criterion & 1458.825 \\
\hline Schwarz criterion & 1461.559 & Hannan-Quinn & 1459.681 \\
\hline Rho & 0.886949 & Durbin-Watson & 0.353703 \\
\hline
\end{tabular}

From the regression result for model 1 presented in Table 6.2 above, minimum capital base of banks has a positive effect on gross domestic product, significant at $1 \%$. The low value of R-squared indicates that there are many other factors aside banks' minimum capital base that account for the changes in GDP. The Pvalue shows that the model is statistically significant.

Table 6. 3: Regression Result for Model 2

Model 1: OLS, using observations 1986-2014 $(\mathrm{T}=29)$

Dependent variable: INR

\begin{tabular}{|l|l|l|l|l|l|}
\hline & Coefficient & Std. Error & t-ratio & $p$-value & \\
\hline Const & 25.749 & 4.13927 & 6.2206 & $<0.00001$ & $* * *$ \\
\hline BMCB & $-5.84513 \mathrm{e}-010$ & $2.76732 \mathrm{e}-010$ & -2.1122 & 0.04443 & $* *$ \\
\hline
\end{tabular}

\begin{tabular}{|l|l|l|l|}
\hline Mean dependent var & 20.33500 & S.D. dependent var & 18.26747 \\
\hline Sum squared resid & 7690.321 & S.E. of regression & 17.19830 \\
\hline R-squared & 0.146460 & Adjusted R-squared & 0.113632 \\
\hline $\mathrm{F}(1,26)$ & 4.461378 & P-value(F) & 0.044432 \\
\hline
\end{tabular}


Banking Reforms And The Effect On Economic Development Of Nigeria

\begin{tabular}{|l|c|l|l|}
\hline Log-likelihood & -118.3475 & Akaike criterion & 240.6949 \\
\hline Schwarz criterion & 243.3593 & Hannan-Quinn & 241.5095 \\
\hline Rho & 0.565417 & Durbin-Watson & 0.815440 \\
\hline
\end{tabular}

From the result of the analysis for model 2, banks' minimum capital base has a negative effect on inflation rate. The effect is significant at 5\% level. Minimum capital base causes $15 \%$ of the changes in inflation. The adjusted R-squared is $11 \%$ and the model is significant at $5 \%$.

Table 6. 4: Regression Result for Model 3

Model 1: OLS, using observations 1986-2014 ( $\mathrm{T}=29)$

Dependent variable: UNR

\begin{tabular}{|l|l|l|l|l|l|}
\hline & Coefficient & Std. Error & t-ratio & $p$-value & \\
\hline Const & 6.68257 & 1.38397 & 4.8286 & 0.00005 & $* * *$ \\
\hline BMCB & $4.39272 \mathrm{e}-010$ & $8.97904 \mathrm{e}-011$ & 4.8922 & 0.00004 & $* * *$ \\
\hline
\end{tabular}

\begin{tabular}{|l|c|l|l|}
\hline Mean dependent var & 10.98966 & S.D. dependent var & 7.755751 \\
\hline Sum squared resid & 892.8225 & S.E. of regression & 5.750435 \\
\hline R-squared & 0.469898 & Adjusted R-squared & 0.450265 \\
\hline F(1,27) & 23.93360 & P-value(F) & 0.000041 \\
\hline Log-likelihood & -90.84205 & Akaike criterion & 185.6841 \\
\hline Schwarz criterion & 188.4187 & Hannan-Quinn & 186.5405 \\
\hline Rho & 0.526346 & Durbin-Watson & 0.948543 \\
\hline
\end{tabular}

From the regression result for model 3, banks' minimum capital base has a positive effect on unemployment rate. The effect is significant at $1 \%$. R-squared shows that $46 \%$ of the variations in the dependent variable are caused by the independent variable. The result further revealed that the model is significant.

\section{Hypotheses Testing}

For proper test, the hypotheses are restated in both null and alternative forms as follows:

\section{Hypothesis 1:}

$\mathrm{H}_{0}$ : Banks' minimum capital base has no significant positive effect on gross domestic product in Nigeria.

$\mathrm{H}_{1}$ : Banks' minimum capital base has significant positive effect on gross domestic product in Nigeria.

From the result of the analysis, minimum capital base of banks has a positive and significant effect on gross domestic product. This means that increase in banks' minimum capital base results in increase in GDP. Therefore, the null hypothesis is rejected while the alternative hypothesis which states that banks' minimum capital base has significant positive effect on gross domestic product in Nigeria is accepted.

\section{Hypothesis 2:}

$\mathrm{H}_{0}$ : Banks' minimum capital base has no significant positive effect on inflation in Nigeria.

$\mathrm{H}_{1}$ : Banks' minimum capital base has significant positive effect on inflation in Nigeria.

From the analysis of model 2, Banks' minimum capital base has a negative effect on inflation rate. The effect is significant at $5 \%$ level. Thus, the null hypothesis which states that banks' minimum capital base has no significant positive effect on inflation in Nigeria is accepted, whereas the alternative hypothesis is rejected.

\section{Hypothesis 3:}

$\mathrm{H}_{0}$ : Banks' minimum capital base has no significant positive effect on unemployment in Nigeria.

$\mathrm{H}_{1}$ : Banks' minimum capital base has significant positive effect on unemployment in Nigeria.

From the result of the analysis presented in Table 6.3, banks' minimum capital base has a positive effect on unemployment rate, significant at $1 \%$. This means that increase in banks' minimum capital base (BMCB) increase unemployment. This could be due to Staff retrenchment in order to meet the minimum capital requirement. Hence, we reject the null hypothesis and accept the alternative hypothesis.

\section{CONCLUSION}

The study concluded that minimum capital requirement of banks is a veritable reform on banks in Nigeria. It yields a positive result on Nigeria's economic development as evidenced in increase in GDP and decrease in inflation. However, the extent of its increase should be taken into consideration in order not to cause increase unemployment through retrenchment of workers. Adequately capitalized banking system will achieve 
macroeconomic stability with eye on managing currency stability (a reduction of currency risk is pre-requisite for a successful integration into global financial markets- exchange rate management) and create an inclusive incentive mechanisms and systems for active participation of all stake-holders in economic development and growth.

\section{RECOMMENDATIONS}

1. The monetary authorities should always take Minimum Capital Base of banks into consideration in banking reforms as it has the capacity to trigger economic development of Nigeria.

2. However, the increase in Minimum Capital Base of banks should not be too high so as not to cause a rise in unemployment.

\section{Journal Articles}

[1]. Bamidele, A and Englama A (1998) 'Macroeconomic Environment Investment Stimulation and Economic Growth and Development: The Nigerian Experience", Rekindling Investment for Economic Development in Nigerian. Selected Papers in Annual Conference, Nigerian Economic Society, Ibadan.[1]

[2]. Schumpeter, J. A. 1934 (2012): The Theory Of Economic Development: An Inquiry Into Profits, Capital, Credit, Interest, and the Business Cycle. (Humblot, Dunker, Eds., \& R. Opie, Trans.) In Alin Croitoru, Journal Of Comparative Research in Anthropology And Sociology, Vol 3, No 2, Winter (2012)[3]

[3]. World Bank (2006) World Development Indicators, World Bank Publication, Washington DC [4]

[4]. Ango Y. I. (2011) The impact of the Banking Sector Reforms on Growth and Development of Entrepreneurs in Nigeria. A paper presented at the $10^{\text {th }}$ International Enterpreeurship Forum, Tamkeen, Bahrain

[5]. Daramola R. Y.(2012) An evaluation of the Impact of the Banking Sector Reforms on Economic Growth in Nigeria. An M.Sc Thesis submitted to the Post Graduate School, Ahmadu Bello University Zaria Nigeria [7]

[6]. Spiegel, M, and Yamori N. (2003). "Determinants of Voluntary Bank Disclosure: Evidence from Japanese Shinkin Banks.” FRB San Francisco, Pacific Basin Working Paper PB03- 03. http:// www. frbsf. org/ publications/ economics/ pbcpapers/2003/pb03-03.pdf [8]

[7]. Board of Governors of the Federal Reserve System. (2000). "Improving Public Disclosure in Banking." Staff Study 173. http://www.federalreserve.gov/pubs/staffstudies/2000-present/173sum.htm[9]

[8]. Flannery, M., Kwan, S.and Nimalendran, M. (2004). 'Market Evidence on the Opaqueness of Banking Firms' Assets.”Journal of Financial Economics 71, pp. 419-460.[10]

[9]. Imoughele, Ehikioya, L., Ismaila, \& Mohammed (2013): Commercial bank credit accessibility and sectoral output performance in a deregulated financial market economy: Empirical evidence from Nigeria. Journal of Finance and Bank Management, 1(2), 36-59. Retrieved from www.aripd.org/jfbm [11]

[10]. Omankhanlen, A. E. (2012): The financial sector reforms and their effect on the Nigerian economy. Economy Transdisciplinary Cognition, 15(2), 45-57. Retrieved from www.ugb.ro/etc [12]

[11]. Fadare, S. O. (2010). Recent banking sector reforms and economic growth in Nigeria. Middle Eastern Finance and Economics, 8, 146-160.[13]

[12]. Ayadi, R., Arbak, E. S., \& De Groen, W. P. (2013): Financial development, bank efficiency and economic growth across the Mediterranean. MEDPRO Technical Report No. 30[14]

[13]. Abu-Zeinab, A. (2013): Patterns of bank credit allocation and economic growth: The case of Denmark 1736 - 2012. Lund Papers in Economic History(General Issues 131), 1-35[15]

[14]. Akpansung, A. O. \& Babalola, S. J. (2012), "Banking Sector Credit and Economic Growth in Nigeria: An Empirical Investigation". CBN Journal of Applied Statistics, 2 (2):51 -62[16]

[15]. Bhusal, B. P. (2012): Impact of financial policy reforms on financial development and economic growth in Nepal International Journal of Business and Social Sciences, 3(14), 33-45[17]

[16]. Abubakar, A., \& Gani, I. M. (2013): Impact of banking sector development on economic growth: Another look at the evidence from Nigeria. Journal of Business Management \& Social Sciences Research (JBM \& SSR), 2(4), 47-57. Retrieved from www.borjournals.com[18]

[17]. Tomola, M. O., Adebisi, T. E., \& Olawale, F. K. (2010): Bank lending, economic growth and the performance of the manufacturing sector in Nigeria. European Scientific Journal, 8(3), 19-36 [19]

Books

[18]. Lewis W.A(1956) Theory of Economic Growth, George Allen and Unwin Ltd. Great Britain $9^{\text {th }}$ Impression Unwin University Books [2]

[19]. Hesse H. Export Diversification and Economic Growth in Breaking into New Markets: Emerging Lessons for Export Diversification edited by Newfarmer R, Shaw Wand Walkenhorst Chapter 3.. World Bank Publication[6]

\section{Other Journal Articles}

[20]. Adam, J.A. (1998): "Financial Intermediation and Economic Growth: Evidence from Nigeria". Journal of Economic Management, 5: 20

[21]. Anyanwu, M. C. (2010): An overview of current banking sector reforms and the real sector of the Nigerian economy. Central Bank of Nigeria Economic and Financial Review, 48(4), 31-56

[22]. Central Bank of Nigeria (CBN) (2012): Banking reform and its impact on the Nigerian economy: Being a lecture delivered by Sanusi Lamido Sanusi CBN Governor. University of Warwick's Economic Summit, UK: Research Department of the Central Bank of Nigeria 
[23]. Central Bank of Nigeria (2012): Statistical Bulletin,. Abuja: Central Bank of Nigeria.

[24]. Ikenna, O. D. (2012). Financial Deregulation in Bounding to Credit Mobilization in Nigeria: A Case for the Real Sectors and SMEs. IOSR Journal of Humanities and Social Science, 5(5), 40-59.

[25]. Iganiga, B. O. (2010) Evaluation of the Nigerian Financial Sector Reforms Using Behavioral Models, Journal of Economics, 1 (2): 65-75

[26]. Sanusi, L. S. (2012):,"Banking Reform and Its Impact on the Nigerian Economy”, Lecture delivered at the University of Warwick's Economic Summit, UK, 17th February 